\title{
Effect of pregnant mares' serum gonadotrophin on the micromorphology of antral follicles in heifers, with special reference to atypical granulosa cells
}

\author{
R. van den Hurk, E. R. Spek, G. Dijkstra, C. J. A. H. V. van Vorstenbosch, \\ S. C. J. Hulshof and S. J. Dieleman \\ Department of Functional Morphology, Faculty of Veterinary Medicine, University of Utrecht, \\ Yalelaan 1,3508 TD Utrecht, Netherlands
}

\begin{abstract}
Summary. Five Dutch-Friesian heifers were injected i.m. with 3000 iu pregnant mares' serum gonadotrophin (PMSG) on day 10 of the oestrous cycle, to study the effects on the number and micromorphological quality of antral follicles ( $\geqslant 0.3 \mathrm{~mm}$ in diameter). The ovaries were collected $48 \mathrm{~h}$ after PMSG injection.

As well as the presence of mitotic figures and the absence of pyknotic nuclei in the granulosa, atypical granulosa cells were found in nonatretic follicles. These cells had an oblong nucleus and stained with toluidine blue. They were characterized by their dark cell matrix, and the presence of numerous free ribosomes and intermediate filaments of varying quantity. Atypical granulosa cells were micromorphologically similar to fibroblast-like cells in the theca. Their presence coincided with the occurrence of degenerative changes in the cytoplasm of nearby granulosa cells and they were more frequent in atretic follicles. The presence of atypical granulosa cells in follicles hitherto called nonatretic is therefore probably associated with the onset of follicular atresia.

In the PMSG-treated heifers, the mean number of large $(\geqslant 6.0 \mathrm{~mm}$ in diameter) antral follicles was greater than in the control group $(18.4 \pm 4.0$ versus $3.0 \pm 1 \cdot 0)$, because of an increase in the number of large nonatretic follicles $(11 \cdot 8 \pm 4.4$ versus $0.4 \pm 0.2)$. After hormone treatment, the mean number of medium-sized $(3.0-5.9 \mathrm{~mm})$ nonatretic follicles also increased $(6 \cdot 4 \pm 1 \cdot 3$ versus $1 \cdot 8 \pm 1 \cdot 0)$. PMSG did not change the mean number of nonatretic follicles $<3.0 \mathrm{~mm}$ or that of atretic follicles in the different size categories. However, when follicles hitherto called nonatretic, with atypical granulosa cells, were taken together with the group of atretic follicles, PMSG appeared to increase the mean number of large atretic follicles $(13.6 \pm 2.4$ versus $3 \cdot 0 \pm 1 \cdot 0$ ). The mean number of medium-sized and large nonatretic follicles without atypical granulosa cells was markedly increased $(3.8 \pm 1 \cdot 0$ versus $0 \cdot 2 \pm 0.2$ and $4 \cdot 6 \pm 1 \cdot 9$ versus $0 \cdot 0$, respectively). The data demonstrate that PMSG stimulates the formation not only of nonatretic follicles $\geqslant 3.0 \mathrm{~mm}$, but also of atretic follicles $\geqslant 6.0 \mathrm{~mm}$.
\end{abstract}

Keywords: ovary; follicle: micromorphology; pregnant mares’ serum gonadotrophin; heifer

\section{Introduction}

Quantitative characters have predominantly been used to assess follicle growth in cows (Rajakoski, 1960; Choudary et al., 1968; Marion et al., 1968; Dufour et al., 1972; Swanson et al., 1972; Mariana \& Huy, 1973; McKenzie \& Kenney, 1973; Matton et al., 1981; Merz et al., 1981; Staigmiller \& England, 1982; Ireland \& Roche, 1983; Monniaux et al., 1983, 1984; Moor et al., 1984; Maurasse et al., 1985). From these investigations it appears that numbers of antral follicles of various sizes 
may vary considerably per cow and per study. This might explain the variable superovulation response after treatment of animals with gonadotrophins (Monniaux et al., 1983). The extent of atresia of antral bovine follicles has also been indicated as one of the determining factors for a successful superovulation response to exogenous gonadotrophins (Lahlou-Kassi \& Mariana, 1984; Spicer \& Echternkamp, 1986; Ireland, 1987). In this respect, it is important to obtain indicators that discriminate between nonatretic and (early) atretic follicles.

Various macroscopical, histological and biochemical characters are used to define follicle quality. The macroscopic appearance of excised follicles correlates with histological signs of atresia in cattle (Kruip \& Dieleman, 1982), and groups of macroscopic qualified follicles can be distinguished from each other by the steroid hormone concentration in the follicular fluid (Kruip \& Dieleman, 1985). Grimes et al. (1987), however, found that macroscopic features of nonexcised follicles were poorly correlated with histological and nonhistological characteristics. They observed, in contrast to findings of Uilenbroek et al. (1980) in rats, that histological signs of atresia preceded loss of steroidogenic function of a follicle. Studies are required to trace the earliest markers of follicular atresia.

This paper presents the effect of pregnant mares' serum gonadotrophin (PMSG) on the number and histological and ultrastructural quality of antral bovine follicles in different size classes. The presence of atypical granulosa cells is proposed as an early marker of follicular atresia.

\title{
Materials and Methods
}

\begin{abstract}
Animals
Studies were carried out from October to December 1989 with 17 Dutch-Friesian heifers. Housing and detection of oestrus were as described by Dieleman $e t$ al. (1983). The time when animals would allow mounting for at least two consecutive times was regarded as the onset of oestrus. The day on which this occurred was defined as day 0 . Luteal function was assessed by collecting blood samples by jugular puncture, and plasma progesterone concentrations were measured according to the method described by Dieleman \& Bevers (1987). Animals used in these studies had $810 \mathrm{nmol}$ progesterone 1 ' in the peripheral blood on day 10 (i.e. during the midluteal stage) of the oestrous cycle.

At day 10, five heifers were injected i.m. with 3000 iu PMSG (Folligon: Intervet International b.v., Boxmeer, Netherlands). Their ovaries were collected by ovariectomy $48 \mathrm{~h}$ after PMSG treatment as described by Dieleman $e t a l$. (1983). Ovaries obtained from untreated heifers on day 12 of the oestrous cycle served as controls.
\end{abstract}

\section{Histology}

Ovaries of the PMSG-treated and of five untreated heifers were fixed in Bouin's fluid, dehydrated in a graded series of ethanol and embedded in paraffin wax. Whole ovaries were sectioned on a microtome. The serial sections, $5 \mu \mathrm{m}$ thick, were stained with Periodic acid-Schiff-haematoxylin. All antral follicles $\geqslant 0.3 \mathrm{~mm}$ were counted and micromorphologically evaluated. The antral follicles were allocated to four size categories according to diameter $(0 \cdot 3-0.9,1 \cdot 0-2 \cdot 9,3 \cdot 0-5.9$ and $\geqslant 6.0 \mathrm{~mm})$. The diameter of each follicle was calculated according to Choudary et al. (1968). Values were corrected for shrinkage ( $10 \%$; Kruip \& Dieleman, 1982).

Based on micromorphological criteria (Kruip \& Dieleman, 1982; Grimes et al., 1987; Spicer et al., 1987), follicles were classified as nonatretic or atretic. Nonatretic follicles were characterized by the presence of many mitotic figures and 0.5 degenerated cells and/or pyknotic nuclei per cross-section in a well-organized granulosa and a continuous basal lamina underneath this granulosa. They had a well-vascularized theca interna with glandular cells and fibroblast-like cells with an orientation parallel to the basement membrane. Nonatretic follicles contained an oocyte at the germinal vesicle stage. Atretic follicles were subdivided into three categories:

(i) light-atretic follicles, with more than five and less than 50 degenerated cells and/or pyknotic nuclei in the granulosa per cross-section, less than ten free-floating cells or atretic bodies in the follicular cavity, few mitotic figures in the granulosa and a well-organized theca interna;

(ii) definite-atretic follicles, with more than 50 pyknotic nuclei and/or degenerated cells and no mitotic figures in an often disorganized and thin granulosa, with many degenerated cells, macrophages and pycnotic nuclei in the follicular cavity and with pyknotic nuclei in a well-organized theca interna; and

(iii) heavy-atretic follicles, almost without a granulosa. The remaining granulosa cells were bordered by pyknotic nuclei, macrophages and degenerated cells. The theca interna varied in thickness and was loosely arranged and disorganized. It contained numerous pyknotic nuclei, lacked mitotic figures and was poorly vascularized. 


\section{Electron microscopy}

From the ovaries of seven untreated heifers, all antral follicles 3-10 $\mathrm{mm}$ in diameter were excised and dissected free of stromal tissue by means of fine watchmaker's forceps. The follicles were measured and macroscopically classified according to Kruip \& Dieleman (1982). Sixteen follicles with a uniformly bright appearance, extensive and extremely fine vascularization, a regular granulosa layer and no free-floating particles in the follicular fluid were classified as nonatretic. These follicles were used for a more detailed micromorphological analysis. They were cut into two halves, the plane of cutting being standardized in an equatorial plane perpendicular to the oophorus-opposite side axis. Prefixative consisted of $2.5 \%$ glutaraldehyde, buffered with $0.075 \mathrm{~mol} \mathrm{Na}$ cacodylate $1^{-1}(\mathrm{pH} 7 \cdot 2)$. Materials were quickly passed through this fixative and transferred to vials containing fresh prefixative. Subsequently, materials were kept for $4 \mathrm{~h}$ at $4^{\circ} \mathrm{C}$. The prefixative was exchanged to a storage buffer consisting of 0.075 mol Na cacodylate $1^{\prime}$ and 0.1 mol sucrose $1^{\prime}(\mathrm{pH} 7 \cdot 2,4 \mathrm{C})$, according to Sabatini et al. (1963). In this buffer, materials were stored for a maximum of 1 week. Materials were postfixed in $2 \% \mathrm{OsO}_{4}$, buffered with $0.075 \mathrm{~mol} \mathrm{Na}$ cacodylate $\mathrm{I}$ ' at $\mathrm{pH} 7.2$ for $1.5 \mathrm{~h}$ at room temperature. Subsequently, $2 \%$ uranylacetate was used as a blockstain. Dehydration in a graded series of acetone was followed by embedding in Araldite (Durcupan ACM-Fluka). Semithin ( $1 \mu \mathrm{m})$ sections were stained with toluidine blue. Ultrathin $(6090 \mathrm{~nm})$ sections were stained with lead citrate (Venable \& Coggeshall, 1965). A Philips 20I electron microscope was used at $60 \mathrm{kV}$ with an objective aperture of $30 \mu \mathrm{m}$.

\section{Statistical analysis}

The nonparametric Mann-Whitney U test was used to compare data from PMSG-treated and untreated heifers on nonatretic and atretic follicles in corresponding size classes. The level of statistical significance was set at $P<0.05$.

\section{Results}

\section{Micromorphology}

Most paraffin-embedded, non-atretic follicles had thin cells with an oblong nucleus locally in their granulosa (Fig. la). These atypical granulosa cells (AGCs) generally were found in the basal area of the granulosa. All 16 nonatretic, araldite-embedded follicles showed AGCs in their granulosa. The cytoplasm of these AGCs strongly stained with toluidine blue (Fig. lb), whereas that of normal granulosa cells stained pale purple. AGCs were frequently accompanied by a small invagination of the basal lamina, pouching into the granulosa (Fig. 1c). The appearance of AGCs strongly resembled that of the fibroblast-like cells from the surrounding thecal layers. AGCs were never seen penetrating the basal lamina. Interruption of the basal lamina was not observed. When present, only a few of these cells (1-10) were generally found per cross-section through a nonatretic follicle. In light- and definite-atretic follicles, AGCs were common in larger numbers (Fig. Id).

Apart from their elongated nucleus, AGCs were ultrastructurally characterized by their dark cell matrix (Fig. 2a) and the presence of numerous intermediate filaments, rough endoplasmic reticulum, mitochondria with lamellar cristae and numerous free ribosomes (Fig. $2 b$ and c). Most granulosa cells contained a round nucleus, a well-developed rough endoplasmic reticulum, a Golgi system and many mitochondria with lamellar cristae; the cell matrix was of moderate electron density. However, the cytoplasm of granulosa cells, in the vicinity of an AGC, often showed marked degenerative changes, such as swollen organelles and loss of organelles in the presence of an intact nucleus (Fig. 3). Glandular-like cells in the theca interna showed a round nucleus, abundant mitochondria, which frequently had tubular cristae, rough and smooth endoplasmic reticulum and few lipid droplets. Thecal fibroblast-like cells had an elongated nucleus and free ribosomes; organelles were sparse. Occasionally, the cytoplasm of these cells contained intermediate filaments.

\section{Effect of PMSG treatment}

An average of $90.6 \pm 23.7$ (SEM) and $113.6 \pm 17 \cdot 3$ antral (nonatretic + atretic) follicles $\geqslant 0.3 \mathrm{~mm}$ was found in untreated and PMSG-treated heifers, respectively. Within this population of antral follicles, PMSG treatment significantly enhanced the mean number of those $\geqslant 6.0 \mathrm{~mm}$ (Table 1). It did not affect the mean number of smaller antral follicles. 

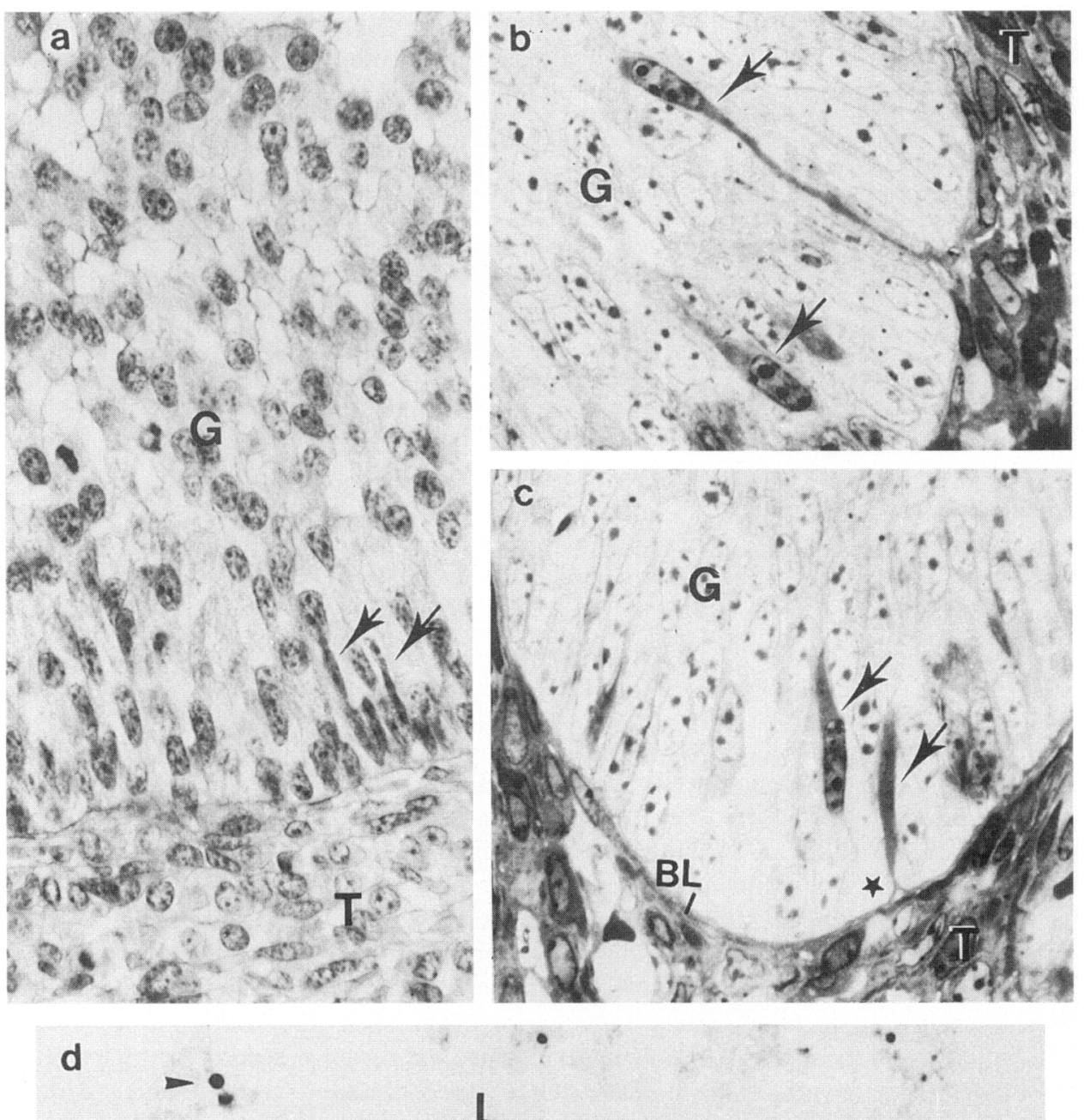

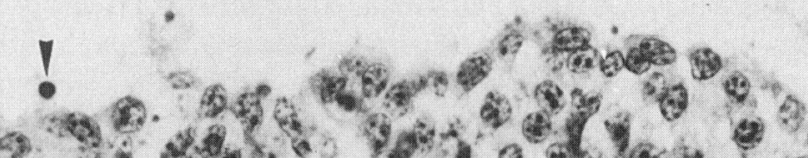

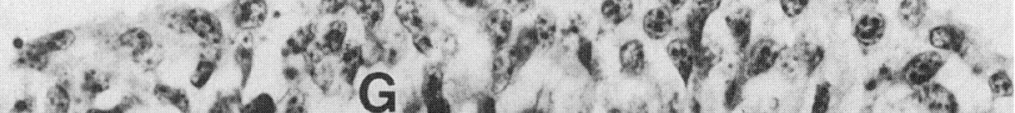

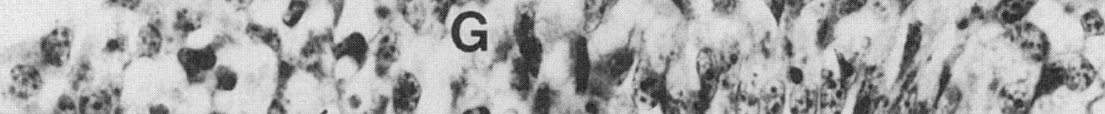
6.

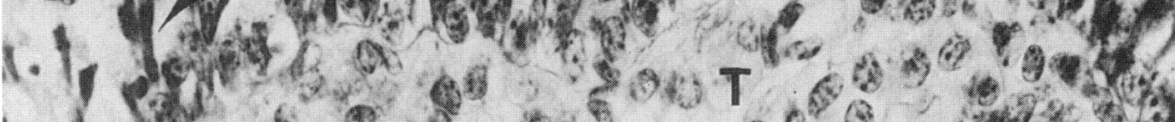

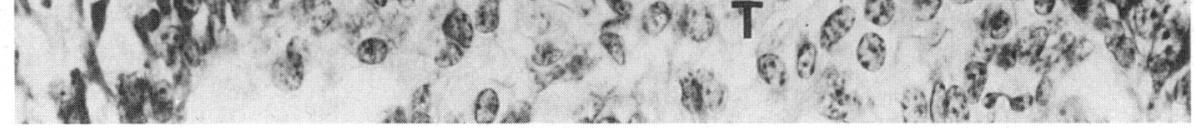


The mean number of nonatretic antral follicles $\geqslant 0.3 \mathrm{~mm}$ significantly increased after PMSG treatment $(62.4 \pm 11.2$ versus $40.4 \pm 9.9 \quad(P<0.05)$; within this population of follicles, significantly more medium-sized $(3.0-5.9 \mathrm{~mm})$ and large $(\geqslant 6.0 \mathrm{~mm})$ follicles were observed (Fig. 4a). Hormone treatment did not affect the mean number of smaller $(0.3-0.9$ and $1.0-2.9 \mathrm{~mm})$ nonatretic follicles.

When the presence of AGCs was used to discriminate nonatretic follicles from atretic follicles, the mean numbers of medium-sized and large nonatretic follicles without AGCs (Fig. 4b) as well as the mean number of large ones with AGCs (Fig. 4c) were markedly greater in PMSG-treated heifers. Of nonatretic follicles $\geqslant 3.0 \mathrm{~mm}$ in the untreated heifers, only $9.1 \%$ lacked AGCs, while these cells were absent in $18.3 \%$ of follicles $<3.0 \mathrm{~mm}$. In the PMSG-treated heifers, AGCs appeared to be absent in $46.7 \%$ of nonatretic follicles $\geqslant 3.0 \mathrm{~mm}$ and $30.7 \%$ of follicles $<3.0 \mathrm{~mm}$.

The mean number of atretic (light-atretic + definite-atretic + heavy-atretic) follicles $\geqslant 0.3 \mathrm{~mm}$ in untreated heifers $(50.2 \pm 13.8)$ was not different from those in PMSG-treated animals $(51 \cdot 2 \pm 6 \cdot 7)$. An effect of hormone treatment was not found, when mean numbers of atretic follicles in different size categories were compared with those in untreated heifers (Fig. 5a). When atretic follicles were subdivided, based on the extent of atresia, hormone treatment did not influence the mean numbers of light-atretic, definite-atretic or heavy-atretic follicles (data not given). Only when follicles hitherto called nonatretic with AGCs were taken together with atretic follicles was the mean number of atretic follicles $\geqslant 6.0 \mathrm{~mm}$ significantly greater after PMSG administration (Fig. 5b).

\section{Discussion}

The mean number of antral follicles per untreated heifer on day 12 in this investigation and the mean numbers of these follicles per size class largely correspond with those described by Rajakoski (1960), Matton et al. (1981) and Moor et al. (1984). Large individual variability of follicle populations has been observed. In the present study, about half of the population of antral follicles appeared atretic. This is in accordance with previous findings by Rajakoski (1960), Mariana \& Huy (1973) and McKenzie \& Kenney (1973). The percentages of atretic follicles were far higher as follicles became larger; from the population of medium-sized $(3.0-5.9 \mathrm{~mm})$ and large $(\geqslant 6.0 \mathrm{~mm})$ follicles 73.7 and $83.3 \%$ were atretic, respectively. Comparable high percentages of atresia in similar-size-class follicles were reported by Kruip (1982) and McNatty et al. (1984).

Initially, micromorphological criteria that were commonly accepted in studies in cattle (Rajakoski, 1960; Marion et al., 1968; Merz et al., 1981; Kruip \& Dieleman, 1982; Grimes et al., 1987; Spicer et al., 1987) were used to discriminate between nonatretic and atretic follicles. This study revealed the appearance of atypical granulosa cells in many nonatretic follicles. These AGCs histologically and ultrastructurally are most similar to fibroblast-like cells in the underlying theca. AGCs, therefore, may originate from the theca interna. On the other hand, these cells may be transformed granulosa cells, since disruption of the basal lamina and penetration of fibroblast-like cells through this lamina have not been observed. The presence of AGCs in nonatretic follicles coincides with the occurrence of degenerative changes in the cytoplasm of nearby granulosa

Fig. 1. Light micrographs of sections of antral follicles, showing atypical granulosa cells (AGCs, arrows) in heifers. Part of (a) a nonatretic follicle, showing a small group of AGCs, Periodic acid-Schiffs (PAS)-haematoxylin staining, $\times 575$; (b) a nonatretic follicle, showing toluidine-blue-stained AGCs, $\times 900$; (c) a nonatretic follicle, showing a small invagination $(\star)$ of the basal lamina (BL) underneath a toluidine-blue-stained AGC, $\times 900$; and (d) a definite atretic follicle, showing numerous AGCs and pyknotic nuclei (arrowheads), PAS-haematoxylin staining, $\times 575 . \mathrm{G}$ : granulosa; T: theca interna; L: follicular lumen. 

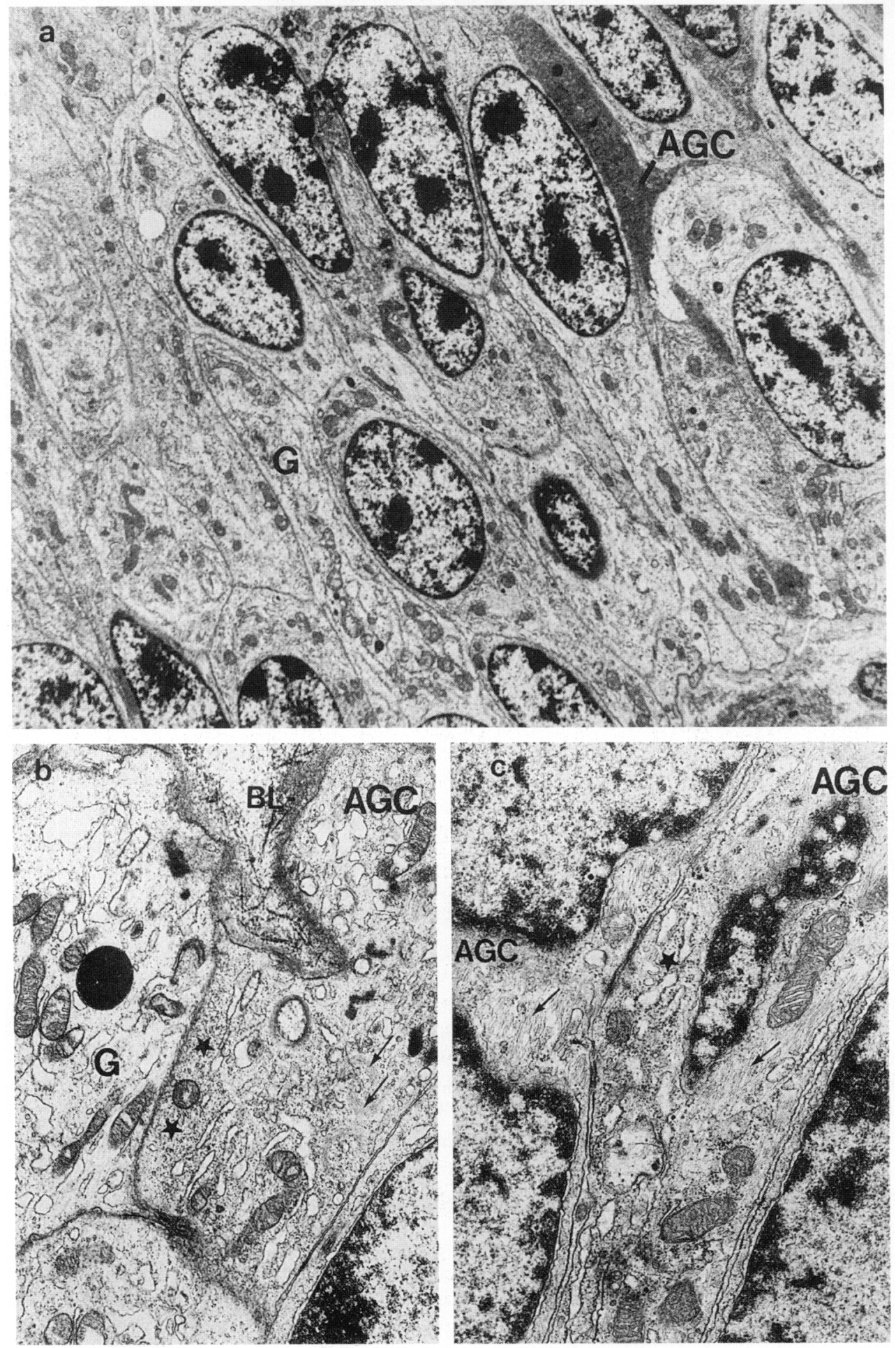

Fig. 2. Electron micrographs of the wall of a nonatretic follicle of a heifer. (a) Part of the granulosa, showing an atypical granulosa cell (AGC) amidst normal granulosa cells $(\mathrm{G})$, $\times 4800$ note the dark cell matrix of the AGC; (b and c) detail of AGCs with intermediate filaments (arrows) and free ribosomes ( $\star$ ), BL: basal lamina. (b) $\times 24000$, (c) $\times 30000$. 


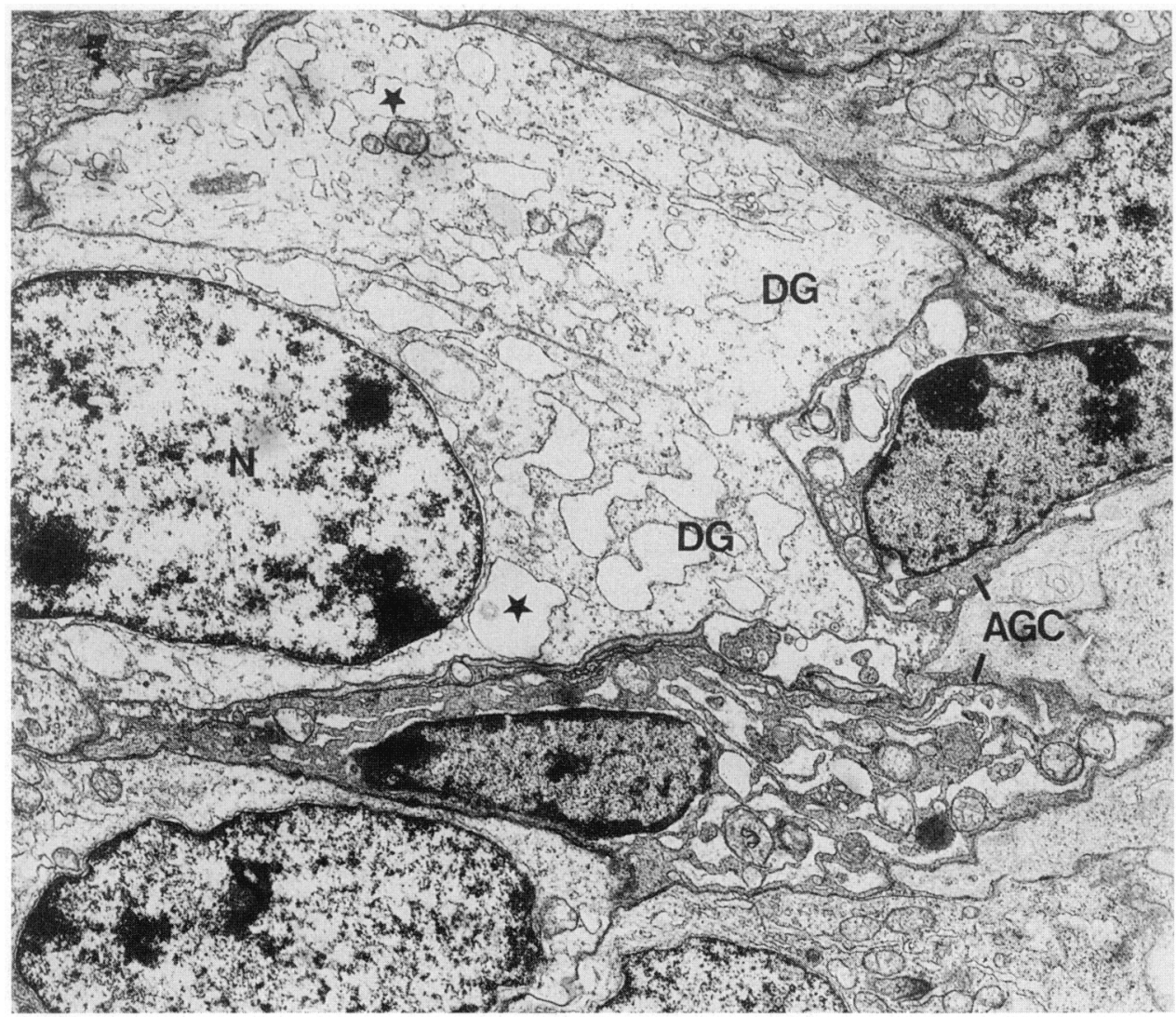

Fig. 3. Electron micrograph of the wall of a nonatretic follicle of a heifer, showing degenerating granulosa cells (DG) in the vicinity of atypical granulosa cells (AGC). Note the swollen organelles $(\star)$ in the presence of an intact nucleus $(N), \times 7100$.

Table 1. Mean number of antral follicles (nonatretic and atretic) per heifer $(n=5)$ in different size classes on day 12 of the oestrous cycle in untreated animals and those treated with pregnant mares' serum gonadotrophin (PMSG)

\begin{tabular}{|c|c|c|}
\hline \multirow{2}{*}{$\begin{array}{l}\text { Size of } \\
\text { antral follicles } \\
(\mathrm{mm})\end{array}$} & \multicolumn{2}{|c|}{$\begin{array}{c}\text { Mean number of } \\
\text { antral follicles (SEM) }\end{array}$} \\
\hline & Control & PMSG \\
\hline $0.3-0.9$ & $42.6(11.6)$ & $54.8(10 \cdot 6)$ \\
\hline $1 \cdot 0-2 \cdot 9$ & $35.6 \quad(8.0)$ & $30 \cdot 8 \quad(4 \cdot 7)$ \\
\hline $3 \cdot 0 \cdot-5 \cdot 9$ & $9 \cdot 4 \quad(3 \cdot 3)$ & $9.6 \quad(1.5)$ \\
\hline$\geqslant 6.0$ & $3.0 \quad(1.0)$ & $18.4(4.0)^{*}$ \\
\hline
\end{tabular}

Significantly different from controls ${ }^{*} P<0 \cdot 01$.

cells. These AGCs were more frequent in atretic follicles. The presence of AGCs is thus probably associated with the onset of atresia. Consequently, a great part of the population of nonatretic follicles, called nonatretic according to current histological criteria, are of suboptimal quality. Fibroblast-like cells within the granulosa have been histologically demonstrated in mammals, but 

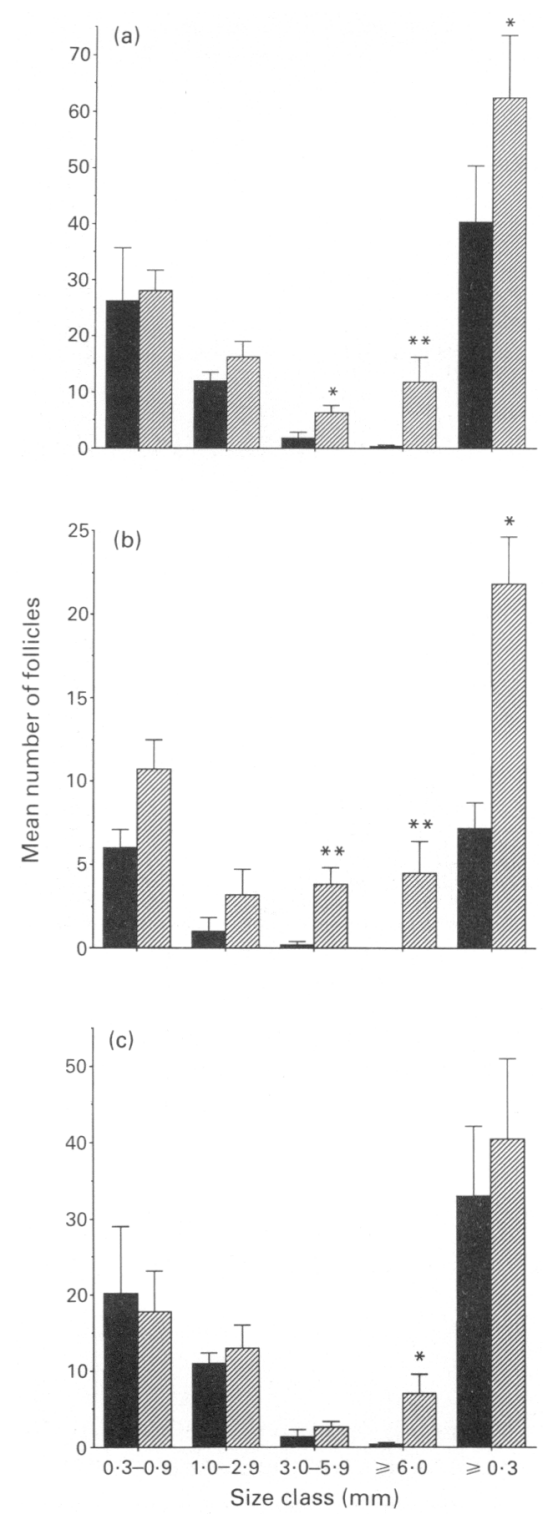

Fig. 4. Mean number of follicles per size category in control heifers $(\boldsymbol{\square})$ and those treated with pregnant mares' serum gonadotrophin $(\bigotimes)$. Significantly different from controls ${ }^{*} P<0.05$; ${ }^{* *} P<0.01$. (a) Nonatretic follicles; (b) nonatretic follicles without atypical granulosa cells (AGCs); (c) nonatretic follicles with AGCs. Vertical bars indicate sEM.

only in atretic follicles with large numbers of pyknotic granulosa cells and extensive folding of the theca interna (Clark, 1923; Ingram, 1962; Horowitz, 1967; Lobel \& Levy, 1968; Priedkalns et al., 1968; Koering, 1969; Brand \& de Jong, 1973; McKenzie \& Kenney, 1973; Monniaux et al., 1984). Most of these authors consider that the fibroblast-like cells originate from the theca interna. However, contrary to Brand \& de Jong (1973), ultrastructural studies of atretic sheep follicles (Hay et al., 1976) did not show the presence of small interruptions in the basal lamina and invasion of thecal elements. The latter authors only observed intact and degenerating granulosa cells in the 


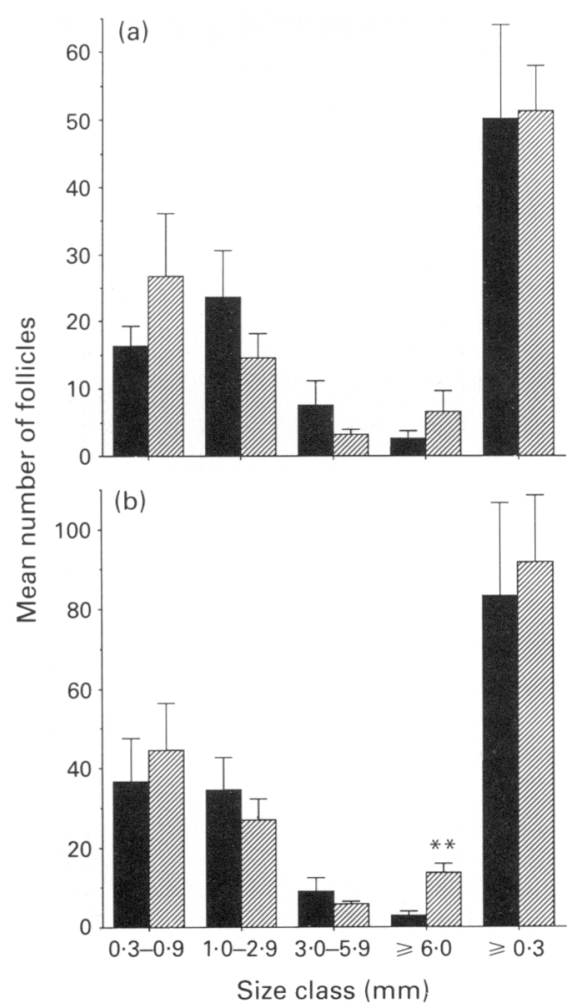

Fig. 5. Mean number of follicles per size category in control heifers $(\boldsymbol{\square})$ and those treated with pregnant mares' serum gonadotrophin (陆). Significantly different from controls $* * P<0.01$. (a) Atretic follicles, (b) atretic plus nonatretic follicles with atypical granulosa cells. Vertical bars indicate SEM.

granulosa of atretic follicles. Thecal elements, found in the granulosa of atretic bovine follicles after histological examination (Priedkalns et al. (1968), were not evident in ultrastructural studies (Priedkalns \& Weber, 1968).

When nonatretic follicles containing AGCs were regarded as light-atretic, only $9 \cdot 1 \%$ of nonatretic follicles $\geqslant 3.0 \mathrm{~mm}$ in the untreated heifers appeared nonatretic. This may indicate that the normal fate of these day- 12 follicles is degeneration. Consequently, macroscopical criteria do not offer a reliable means of identifying healthy bovine follicles, since all 16 excised macroscopic nonatretic follicles had AGCs. This conclusion contrasts with the opinion of Kruip \& Dieleman (1982). Grimes et al. (1987) did not find a correlation between the macroscopic and the microscopic images of antral follicles, but they used nonexcised follicles in their studies.

PMSG treatment results in more large $(\geqslant 6.0 \mathrm{~mm})$ antral follicles. This effect is due to an increase in the number of large nonatretic follicles. The number of medium-sized $(3.0-5 \cdot 9 \mathrm{~mm})$ nonatretic follicles also increased in the hormone-treated heifers. PMSG did not affect the number of nonatretic follicles $<3.0 \mathrm{~mm}$ or that of atretic follicles in the different size categories. The data indicate that PMSG stimulates the formation of large nonatretic antral follicles from the population of smaller follicles and the recruitment of new small antral follicles from the population of preantral follicles. The present data partly contradict those of Monniaux et al. (1984) and Moor et al. (1984), who found that PMSG did not change the number of nonatretic antral follicles, but reduced the incidence of atresia among antral follicles; but they did show a significant increase in mitotic activity of granulosa cells in preantral follicles of superovulated animals. Moor et al. (1984) concluded that PMSG promotes recruitment of antral follicles and prevents some normal follicles 
from becoming atretic or converts some atretic follicles to a normal state. Similar hypotheses were proposed after various studies in rodents (for review, see Greenwald \& Terranova, 1988). Recent studies in sheep (Driancourt et al., 1987) and rats (Hirshfield, 1989), however, demonstrated that exogenous gonadotrophins do not act on follicles by rescuing atretic follicles.

PMSG treatment results in more nonatretic follicles $\geqslant 3.0 \mathrm{~mm}$ without AGCs and in more nonatretic follicles $\geqslant 6.0 \mathrm{~mm}$ with AGCs. This latter group of follicles with AGCs may be considered as light-atretic. When nonatretic follicles with AGCs are taken together with the group of atretic follicles, a significant increase in the population of atretic follicles $\geqslant 6.0 \mathrm{~mm}$ was found after PMSG treatment.

The present data show that the presence of AGCs in follicles hitherto called nonatretic is probably associated with the onset of atresia. When the presence of AGCs is used to discriminate between nonatretic and atretic follicles, PMSG treatment stimulates not only the formation of medium-sized and large nonatretic follicles, but also of large atretic follicles.

We thank M. A. M. Taverne for critically reviewing the manuscript, P. L. A. M. Vos and J. H. M. Lutz for technical assistance, J. Laven for statistical advice and F. Kindt and H. de Waal for preparing the figures.

\section{References}

Brand, A. \& de Jong, W.H.R. (1973) Qualitative and quantitative micromorphological investigations of the tertiary follicle population during the oestrous cycle in sheep. Journal of Reproduction and Fertility. 33, $431-439$.

Choudary, J.B., Gier, H.T. \& Marion, G.B. (1968) Cyclic changes in bovine vesicular follicles. Journal of Animal Science 27, 468-471.

Clark, E.B. (1923) Observations on the ova and ovaries of the guinea pig, Cavia cobaya. Anatomical Record 25, 313-331.

Dieleman, S.J. \& Bevers, M.M. (1987) Effects of monoclonal antibody against PMSG administered shortly after the preovulatory LH surge on time and number of ovulations in PMSG/PG-treated cows. Journal of Reproduction and Fertility 81, 533-542.

Dieleman, S.J., Kruip, Th.A.M., Fontijne, P., de Jong, W.H.R. \& Van Der Weyden, G.C. (1983) Changes in oestradiol, progesterone and testosterone concentrations in follicular fluid and in the micromorphology of preovulatory bovine follicles relative to the peak of luteinizing hormone. Journal of Endocrinology 97, 31. 42.

Driancourt, M.A., Fry, R.C., Clarke, I.J. \& Cahill, L.P. (1987) Follicular growth and regression during the 8 days after hypophysectomy in sheep. Journal of Reproduction and Fertility 79, 635-644.

Dufour, J., Whitmore, H.L., Ginther, O.J. \& Casida, L.E. (1972) Identification of the ovulating follicle by its size on different days of the estrous cycle in heifers. Journal of Animal Science 34, 85-87.

Greenwald, G.S. \& Terranova, P.F. (1988) Folicular selection and its control. In The Physiology of Reproduction, pp. 387-444. Eds E. Knobil \& J. Neill. Raven Press, New York.

Grimes, R.W., Matton, P. \& Ireland, J.J. (1987) A comparison of histological and non-histological indices of atresia and follicular function. Biology of Reproduction 37, 82-88.
Hay, M.F., Cran, D.G. \& Moor, R.M. (1976) Structural changes occurring during atresia in sheep ovarian follicles. Cell and Tissue Research 169, 515-529.

Hirshfield, A.N. (1989) Rescue of atretic follicles in vitro and in vivo. Biology of Reproduction 40, 181-190.

Horowitz, M. (1967) The anovular corpus luteum in the golden hamster (Mesocricetus auratus Waterhouse) and comparison with the normal corpus luteum and follicle of atresia. Acta Anatomica 66, 199-225.

Ingram, D.L. (1962) Atresia. In The Ovary, Vol. 1, pp. 247-273. Ed. S. Zuckerman. Academic Press, New York.

Ireland, J.J. (1987) Control of follicular growth and development. Journal of Reproduction and Fertility Supplement 34, 39-54.

Ireland, J.J. \& Roche, J.F. (1983) Development of nonovulatory antral follicles in heifers; changes in steroids in follicular fluid and receptors for gonadotropins. Endocrinology 112, 150-156.

Koering, M.J. (1969) Cyclic changes in ovarian morphology during the menstrual cycle in Macaca mulala. American Journal of Anatomy 126, 73-101.

Kruip, Th.A.M. (1982) Macroscopic identification of tertiary follicles $>2 \mathrm{~mm}$ in the ovaries of cycling cows. In Factors Influencing Fertility in the post partum Cow, pp. 95-101. Eds H. Karg \& E. Schallenberger. Martinus Nijhoff Publishers, The Hague.

Kruip, Th.A.M. \& Dieleman, S.J. (1982) Macroscopic classification of bovine follicles and its validation by micromorphological and steroid biochemical procedures. Reproduction Nutrition and Development 22, 465-473.

Kruip, Th.A.M. \& Dieleman, S.J. (1985) Steroid hormone concentrations in the fluid of bovine follicles relative to size, quality and stage of the oestrous cycle. Theriogenology 24, 395-407.

Lahlou-Kassi, A. \& Mariana, J.C. (1984) Ovarian follicular growth during the oestrous cycle in two breeds of ewes of different ovulation rate, the D'Man and the 
Timahdite. Journal of Reproduction and Fertility $\mathbf{7 2}$, $301-310$.

Lobel, B.L. \& Levy, E. (1968) Growth and maturation of follicles. Enzymic correlates of development, secretory function and regression of follicles and corpora lutea in the bovine ovary. Acta Endocrinologica Supplementum 132, 763.

McKenzie, B.E. \& Kenney, R.M. (1973) Histologic features of ovarian follicles of gonadotropin-injected heifers. American Journal of Veterinary Science 34, 1033-1040.

MeNatty, K.P., Heath, D.A., Henderson, K.M., Lun, S., Hurst, P.R., Ellis, L.M., Montgomery, G.W., Morrison, L. \& Thurley, D.C. (1984) Some aspects of thecal and granulosa cell function during follicular development in the bovine ovary. Journal of Reproduction and Fertility. 72, 39. 53.

Mariana, J.C. \& Huy, N.N. (1973) Folliculogenèse chez la vache. Annales de biologie animale biochimie et biophysique. Hors-série 13, 211-221.

Marion, G.B., Gier, H.T. \& Choudary, J.B. (1968) Micromorphology of the bovine follicular system. Journal of Animal Science 27, 45I-465.

Matton, P., Adelakoun, V., Couture, Y. \& Dufour, J.J. (1981) Growth and replacement of the bovine ovarian follicles during the estrous cycle. Journal of Animal Science 52, 813-820.

Maurasse, C., Matton, P. \& Dufour, J.J. (1985) Ovarian follicular populations at two stages of an estrous cycle in heifers given high energy diets. Journal of Animal Science 61, 1194-1200.

Merz, E.A., Hauser, E.R. \& England, B.G. (1981) Ovarian function in the cycling cow: relationship between gonadotropin binding to theca and granulosa and steroidogenesis in individual follicles. Journal of Animal Science 52, 1457-1467.

Monniaux, D., Chupin, D. \& Saumande, J. (1983) Superovulatory responses of cattle. Theriogenology $19,55-81$.

Monniaux, D., Mariana, J.C. \& Gibson, W.R. (1984) Action of PMSG on follicular populations in the heifer. Journal of Reproduction and Fertility $\mathbf{7 0}$, 243-253.

Moor, R.M., Kruip, Th.A.M. \& Green, D. (1984) Intraovarian control of folliculogenesis: limits to superovulation? Theriogenology 21, 103-116.
Priedkalns, J. \& Weber, A.F. (1968) Ultrastructural studies of the bovine Graafian follicle and corpus luteum. Zeitschrift für Zellforschung und mikroskopische Anatomie 91, 554--573.

Priedkalns, J., Weber, A.F. \& Zemjanis, R. (1968) Qualitative and quantitative morphological studies of the cells of the membrana granulosa, theca interna and corpus luteum of the bovine ovary. Zeitschrift für Zellforschung und mikroskopische Anatomie 85, $501-520$.

Rajakoski, E. (1960) The ovarian follicular system in sexually mature heifers with special reference to seasonal, cyclical, and left-right variations. Acta Endocrinologica Supplementum 52, 6-68.

Sabatini, D.D., Bensch, K. \& Barnett, R.J. (1963) The preservation of cellular ultrastructure and enzymatic activity of glutaraldehyde fixation. Journal of Cell Biology 17, 19-58.

Spicer, L.J. \& Echternkamp, S.E. (1986) Ovarian follicular growth, function and turnover in cattle: a review. Journal of Animal Science 62, 428-451.

Spicer, L.J., Matton, P., Echternkamp, S.E., Convey, E.M. \& Tucker, H.A. (1987) Relationships between histological signs of atresia, steroids in follicular fluid, and gonadotropin binding in individual bovine antral follicles during postpartum anovulation. Biology of Reproduction 36, 890-898.

Staigmiller, R.B. \& England, B.G. (1982) Folliculogenesis in the bovine. Theriogenology 17, 43-51.

Swanson, L.V., Hafs, H.D. \& Morrow, D.A. (1972) Ovarian characteristics and serum LH, prolactin, progesterone and glucocorticoid from first estrus to breeding size in Holstein heifers. Journal of Animal Science 34, 284-293.

Uilenbroek, J.Th.J., Woutersen, P.J.A. \& Van Der Schoot, P. (1980) Atresia of preovulatory follicles: gonadotropin binding and steroidogenic activity. Biology of Reproduction 23, 219-229.

Venable, J.H. \& Coggeshall, R. (1965) A simplified lead citrate stain for use in electron microscopy. Journal of Cell Biology 25, 407-408.

Received 17 July 1991 